DOI: $10.17805 /$ trudy.2015.4.9

\title{
СТУДЕНТЫ И «СВОБОДНЫЕ ДЕНЬГИ»
}

\author{
Н. А. Перинская \\ (Московский гуманитарный университет)
}

Аннотация: В статье представлен анализ данных экспресс-опроса первокурсников МосГУ, проведенного в феврале 2015 2., в котором косвенно проявились их ценностные ориентации и определенные мировоззренческие позиции.

Ключевые слова: молодежь, студенчество, ценностные ориентации, социология молодежи, Московский гуманитарный университет.

\section{STUDENTS AND “THE MONEY TO SPARE”}

\author{
N. A. Perinskaya \\ (Moscow University for the Humanities)
}

Abstract: The article presents the outcome of an express questionnaire survey of freshmen at Moscow University for the Humanities, which was held in April 2015. The survey revealed students'value orientations and specific worldview attitudes.

Keywords: youth, students, value orientations, sociology of youth, Moscow University for the Humanities.

В Московском гуманитарном университете давно установилась практика изучения студенческого контингента с применением социологического инструментария по определенному исследовательскому маршруту. На первом курсе проводится сплошной анкетный опрос «Первокурсник Московского гуманитарного университета», в конце учебного года сплошной анкетный опрос «Учебно-воспитательный процесс в оценках студентов», охватывающий все курсу и все формы обучения. Эти исследования в 2004-2009 гг. проводились в тесной увязке с крупным мониторинговым исследованием «Российский вуз глазами студентов», рамках которого также велись полевые исследования среди студентов Московского гуманитарного университета. Исследовательские материалы этих исследований опубликованы в различных изданиях (Первокурсник ... , 
2005ab; Ильинский, Луков, 2009; Луков, Гневашева, 2008, 2009; Гневашева, Луков, Луков, 2008; Луков, 2005, 2015; Биченко, 2009). Они отражают основные позиции научной школы Московского гуманитарного университета в исследовании молодежной проблематики, включая общие вопросы социологии молодежи и социологии образования, проблемы социализации личности, междисциплинарные исследования молодежи, молодежного движения, молодежной политики (Ильинский, 2001, 2002, 2004, 2005; 2010, 2012; Ковалева, 2006, 2007, 2011, 2012; Жулковска, Ковалева, Луков, 2003; Селиверстова, Юмашева, 2009; Ковалева, Богданова, 2012; Ковалева, Луков, 1999, 2012; Ковалева, Реут, 2001; Луков, 2012, 2013; Луков, Погорский, 2014; Луков, Жулковска, 2013; Диалог ..., 2010; Государственная молодежная политика ... , 2013: Электр. ресурс; Зубарев, 2014, Электр. ресурс).

В рамках этой работы проводятся также небольшие по объему исследования, которые проясняют отдельные стороны социального облика современного российского студенчества. Одним из таких исследований стал проведенный в феврале 2015 г. письменный экспресс-опрос первокурсников факультета экономики и управления Московского гуманитарного университета, которым было предложено ответить на открытый вопрос «Что бы Вы приобрели, если бы у Вас появились «свободные деньги»?» В опросе приняли участие 86 первокурсников. Для обработки полученных ответов был подготовлен кодировочный бланк (выписывались варианты ответов 10-20 респондентов на этот вопрос, затем ответы были сгруппированы по смысловому содержанию и размещены вертикально в линейной форме; полученным вариантам присваивались порядковые числовые коды в виде натурального числа). Далее обрабатывались полученные данные. Они отображены на таблице 1.

Таблица 1. Ответы респондентов на вопрос: «Что бы Вы приобрели, если бы у Вас появились «свободные деньги?» (респонденты могли указать более одного варианта ответов, представлены популярные ответы)

\begin{tabular}{|c|l|c|c|}
\hline $\begin{array}{c}\text { № } \\
\text { п/п }\end{array}$ & \multicolumn{1}{|c|}{ Варианты ответов } & $\begin{array}{c}\text { Количество } \\
\text { ответов }\end{array}$ & в \% \\
\hline 1 & $\begin{array}{l}\text { Помощь родным и близким, } \\
\text { благотворительность }\end{array}$ & 59 & 69 \\
\hline 2 & Недвижимость (квартира, дом и т. д.) & 58 & 68 \\
\hline $3-4$ & Вложения в свой бизнес & 30 & 35 \\
\hline $3-4$ & Транспортное средство & 30 & 35 \\
\hline 5 & Путешествия & 12 & 14 \\
\hline 6 & $\begin{array}{l}\text { Другое («не стал бы тратить деньги», } \\
\text { «оплатил бы учебу» и т. д.) }\end{array}$ & 17 & 20 \\
\hline
\end{tabular}


Обращает на себя внимание тот факт, что наибольшее число опрошенных (69\%) высказали намерение помочь родным и близким (32\%) или израсходовать деньги на благотворительность (помощь больным детям (7\%), детским домам (6\%); инвестирование строительства церквей, больниц, ремонт автомобильных дорог и т. д. Такой выбор отражает высокую значимость для опрошенных студентов ценностей добра, сострадания, участия в судьбах других людей.

Появление «свободных денег» большое число опрошенных (68\%) связывает с приобретением недвижимости (квартиры, дома за городом или за рубежом). Этот выбор, скорее всего, связан с распространенным мнением о том, что деньги наилучшим образом сохраняются в недвижимости, которая выступает гарантом определенного уровня жизни и не становится дешевле.

Несмотря на то, что студенты учатся на факультете экономики и управления, только 35\% респондентов вложили бы деньги в свой бизнес. Однако таковой выбор отражает желание студентов вложить полученные деньги в «актив», тем самым приумножить их.

Каждый третий опрошенный на «свободные деньги» приобрел бы транспортное средство. Нужно отметить то, что студенты указывали исключительно дорогие марки машин. Это говорит о том, что у них есть желание приобщиться к высшему классу общества. Следовательно, престиж как ценность имеет высокую значимость для опрошенных студентов.

На путешествия потратили бы деньги 14\% опрошенных. Это связано с желанием расширить свой кругозор, получить новые эмоции.

Велика ли надежность полученных данных? В какой мере мы действительно получили информацию, фиксирующую некоторые характеристики каждой личности? Отвечая на этот вопрос, который был задан неожиданно, студенты не имели времени на размышления, на обсуждение с однокурсниками вариантов ответа. И, главное, респонденты не знали, как должен выглядеть ответ на заданный вопрос в его наиболее верном варианте, чтобы выглядеть лучше. Скорее ответ сформировался под воздействием «значимых других» и уникального «Я».

Конечно, приведенные данные не дают оснований делать какие-то выводы о тех или иных личностных качествах студентов первого курса факультета экономики и управления. Вместе с тем, нельзя не задержать внимание на этой таблице и не попытаться сделать несколько замечаний о предпочтениях респондентов.

Во-первых, приведенные данные показывают на сравнительно благополучный жизненный уровень опрошенных студентов. В их ответах не обозначилась озабоченность приобретением предметов первой необходимости (питание, одежда, мебель). Покупку компьютера, мобильно- 
го телефона, смартфона, планшета также не указал никто. Здесь следует учесть, что все опрошенные студенты происходят из семей, которые оплачивают обучение и не настаивают на непременном трудоустройстве сына или дочери. Это означает, что в родительской семье есть определенный достаток.

Во-вторых, результаты опроса подтверждают ориентацию студентов на нравственные нормы, составляющие основы совместной жизни людей в российском обществе. Для студентов значимость такой ценности, как доброта была установлена в ходе мониторингового исследования, проведенного Институтом фундаментальных и прикладных исследований и кафедрой социологии МосГУ (опрошено в 2014 г. 673 студента, в 2015 г. -624 студента). В ответах на вопрос о тех качествах, которые нынешние студенты хотели бы воспитать в своих детях, на первом месте стоит доброта. Доброта выделена каждым четвертым из опрошенных студентов и среди качеств, ценимых ими в других людях. Все это дает основание предположить, что доброта как социальное качество будет воспроизводиться в новых поколениях россиян.

\section{СПИСОК ЛИТЕРАТУРЫ}

Биченко, И. Г. (2009) Ценностные ориентации студентов российских вузов в условиях социальной аномии : автореф. дис.... канд. социол. наук. M. 18 c.

Гневашева, В. А., Луков, В. А., Луков, С. В. (2008) Студент Московского гуманитарного университета: социализационная динамика : Сравнительный анализ материалов мониторинга (этапы 2005 и 2007 гг.). М. : Изд-во Моск. гуманит. ун-та. 24 с.

Государственная молодежная политика: российская и мировая практика реализации в обществе инновационного потенциала новых поколений (2013) : науч. монография [Электронный ресурс] / под общ.ред. Вал. А. Лукова. М. : Изд-во Моск. гуманит. ун-та, 2013. 718 с. URL: http://hdirussia. ru/assets/files/Books/State-Youth-Policy.pdf (дата обращения 01.07.2015).

Диалог организационных культур в создании общеевропейского пространства высшего образования : Реализация принципов Болонского процесса в международных образовательных программах с участием России (2010) : монография / С. В. Луков (рук.), Б. Н. Гайдин, В. А. Гневашева и др. М. : Изд-во Моск. гуманит. ун-та. 260 с.

Жулковска, Т., Ковалева, А. И., Луков, В. А. (2003) «Ненормальные» в обществе: Социализация людей с ограниченными интеллектуальными возможностями. Москва-Щецин : Изд-во Моск. гуманит. ун-та. 432 с.

Зубарев, Д. Ю. (2014) Молодежь в исследованиях научной школы социологии молодежи Московского гуманитарного университета [Элек- 
тронный ресурс] // Информационный гуманитарный портал «Знание. Понимание. Умение». № 2 (март - апрель). URL: http://www.zpu-journal. ru/e-zpu/2014/2/Zubarev_Youth-Sociology-School-Thought/ [архивировано в WebCite] (дата обращения: 01.07.2015).

Ильинский, И. М. (2001) Молодежь и молодежная политика. М. : Голос. 694 c.

Ильинский, И. М. (2002) Образовательная революция. М. : Изд-во Моск. гуманит.-социальн. академии. 592 с.

Ильинский, И. М. (2004) Негосударственные вузы России: опыт самоидентификации. М. : Изд-во Моск. гуманит. ун-та. 350 с.

Ильинский, И. М. (2005) Молодежь как будущее России в категориях войны // Знание. Понимание. Умение. №3. С. 5-17.

Ильинский, И. М. (2010) Куда идем, родимое образование?.. (беглые заметки по поводу законопроекта «Об образовании в Российской Федерации») // Знание. Понимание. Умение. №3. С. 3-26.

Ильинский, И. М. (2012) «Модернизация» российского образования в контексте мировой глобализации // Знание. Понимание. Умение. № 3. С. $3-23$.

Ильинский, И. М., Луков, В. А. (2009) Российский вуз глазами студента // Аккредитация в образовании. Ноябрь, № 34. С. 75-77.

Ковалева, А. И. (2006) Личность молодого человека // Знание. Понимание. Умение. №2. С. 221-222.

Ковалева, А. И. (2007) Проблемы результативности социализации молодежи в изменяющемся обществе // Вестник Международной академии наук (Русская секция). №1. С. 73-77.

Ковалева, А. И. (2011) Общество и личность. М. : Изд-во Моск. гуманит. ун-та. 204 с.

Ковалева, А. И. (2012) Методологические проблемы исследования социализации // Знание. Понимание. Умение. №2. С. 19-24.

Ковалева, А. И., Богданова, В. В. (2012) Траектория социализации : монография. М. : Изд-во Моск. гуманит. ун-та. 184 с.

Ковалева, А. И., Луков, В. А. (1999) Социология молодежи : Теоретические вопросы. М. : Социум. 351 с.

Ковалева, А. И., Луков, В. А. (2012) Социализация: социальнофилософский, социологический и социально-психологический аспекты понимания // Философия и культура. № 3. С. 27-35.

Ковалева, А. И., Реут, М. Н. (2001) Социализация неслышашей молодежи. М. : Социум. 222 с.

Луков, В. А. (2005) Студент и его вуз: анализ мониторингового исследования // Знание. Понимание. Умение. № 4. С. 150-154.

Луков, В. А. (2012) Теории молодежи: Междисциплинарное исследование. М. : Канон+. 528 с. 
Луков, В. А. (2013) Ильинский Игорь Михайлович о проблемах молодежи и молодежной политики // YouthWorldPolitic. № 2. C. 107-111.

Луков, В. А., Гневашева, В. А. (2008) Российский студент: социальный облик : По материалам мониторинга «Российский вуз глазами студентов» (этап 2007 года). М. : Изд-во Моск. гуманит. ун-та. 54 с.

Луков, В. А., Гневашева, В. А. (2009) Человеческий потенциал студента - образовательный потенциал вуза : По материалам мониторинга «Российский вуз глазами студентов» (этапы 2004-2008 годов). М. : Изд-во Моск. гуманит. ун-та. 69 с.

Луков, В. А., Погорский, Э. К. (2014) Информационное общество и молодежь : науч. монография. М. : Изд-во Моск. гуманит. ун-та. 160 с.

Луков, В. А. (2015) Каков он - первокурсник факультета рекламы // Вестник Московского гуманитарного университета. № 2. С. 14-16.

Луков, Вл. А., Жулковска, Т. (2013) Ковалева Антонина Ивановна о социализации молодежи // Youth. World. Politic. № 2. C. 117-122.

Луков, С. В., Гневашева, В. А. (2009) Динамические оценки ценностных ориентаций студентов в системе высшего профессионального образования за период 2001-2009 гг. : По материалам мониторинга «Российский вуз глазами студентов». М. : Изд-во Моск. гуманит. ун-та. 24 с.

Первокурсник Московского гуманитарного университета: 2004 год : Итоги междисциплинарного исследования. Ч. 1 (2005а) / под общ. ред. В. А. Лукова, А. И. Ковалевой. М. : Изд-во Моск. гуманит. ин-та. 100 с.

Первокурсник Московского гуманитарного университета: 2004 год : Итоги междисциплинарного исследования. Ч. 2 (2005b) / под общ. ред. В. А. Лукова, А. И. Ковалевой. М. : Изд-во Моск. гуманит. ин-та. 32 с.

Селиверстова, Н. А., Юмашева, Н. Д. (2009) Чтение в студенческой среде: опыт социол. исслед. М. : РКП. 108 с.

Перинская Наталья Алексеевна - кандидат социологических наук, доцент кафедры социологии Московского гуманитарного университета. Адрес: 111395, Россия, г. Москва, ул. Юности, д. 5. Тел.: +7 (499) 374-60-21. Эл. адрес: ptv@front.ru

Perinskaya Natalia Alekseyevna, Candidate of Sociology, Associate Professor, Department of Sociology, Moscow University for the Humanities. Postal address: 5 Yunosti St., 111395 Moscow, Russian Federation. Tel.: +7 (499) 374-60-21.E-mail:ptv@front.ru 